\title{
Enablers and perceived risks of Covid-19 vaccine uptake among health care providers in Nigeria
}

Valentine Chidi Obidile 1, Onyeka Chukwudalu Ekwebene 2, ${ }^{\text {*, }}$ Precious Chidozie Azubuike ${ }^{3}$, Chioma Phyllis Nnamani ${ }^{4}$, Nehemiah Emono Dankano ${ }^{5}$ and Michel Chiedu Egbuniwe 6

\author{
${ }^{1}$ Centre for Integrated Health Program, Abuja, Nigeria. \\ ${ }^{2}$ Faculty of Medicine, Nnamdi Azikiwe University, Nnewi Campus, Anambra State, Nigeria. \\ ${ }^{3}$ Department of Public Health, College Of Medical Sciences, University Of Calabar, Nigeria \\ ${ }^{4}$ Department of Family Medicine, Nnamdi Azikiwe University Teaching Hospital, Nnewi, Anambra State, \\ Nigeria. ${ }^{5}$ First Referral Hospital Mutum Biyu, Taraba Stae, Nigeria. \\ ${ }^{6}$ Nursing Services Department, Nnamrdi Azikiwe University Teaching Hospital, Nnewi, Anambra State, Nigeria.
}

Magna Scientia Advanced Research and Reviews, 2021, 01(03), 062-067

Publication history: Received on 06 February 2021; revised on 10 March 2021; accepted on 12 March 2021

Article DOI: https://doi.org/10.30574/msarr.2021.1.3.0027

\begin{abstract}
Vaccines found to be highly effective will enable uptake than those with low effectiveness. Health care providers in Nigeria aged 18 years and above participated in this study. The study was conducted to assess the enablers and perceived risks of Covid-19 vaccination among healthcare providers in Nigeria. A snowball sampling technique was relied upon in the distribution of the online questionnaires sent in the form of a link through social media outlets such as Whatsapp, Face book and emails within four weeks interval. The analysis was performed using the Statistical Software Package SPSS version 22.0.Four Hundred and forty-five respondents filled the questionnaire from the six geopolitical zones of the country. It was observed that safety of the vaccine, proven efficacy and good knowledge of the vaccine were enablers to the Covid-19 vaccine uptake. This finding shows that a higher proportion of health care providers was in support of the covid-19 vaccine under the presumption that the vaccine was proven effective. 243(54.6\%) perceived that a clinical sequalae may result later after they take the Covid-19 vaccine, 207(46.5\%) perceived that the clinical trial of the Covid-19 vaccine was inadequate and $187(42.0 \%)$ perceived that a new virus strain may emerge and therefore, bring about another vaccine. In addition, $180(40.4 \%)$ respondents perceived that the Covid-19 vaccine might worsen their co-morbidities and 61(13.7\%) showed concerns as they think the Covid-19 vaccine may affect their immune systems and make them more susceptible to new viral strains. Proven vaccine safety, proven efficacy and good knowledge were identified as enablers of the covid-19 vaccine while clinical sequalae and inadequate clinical trials were noted as the perceived risks of covid-19 vaccine uptake among health care providers.
\end{abstract}

Keywords: Acceptability; Hesitancy; Vaccine and Health Care Providers

\section{Introduction}

The Corona virus disease 2019 (Covid-19) has become a worldwide pandemic spreading across the globe with millions of people infected and recording hundred thousands of deaths[1][2]. Nigeria is also among the vulnerable countries in Africa predicted to experience accelerated spread of the Covid-19 Virus owing largely to the weak state of health infrastructure and health systems [4]. As at 5th March 2021, Nigeria has recorded 158, 042 confirmed cases, 137,025 discharged cases and 1954 deaths [3].

*Corresponding author: Ekwebene Onyeka Chukwudalu; Email: chukwudaluonyeka@gmail.com

Faculty of Medicine, Nnamdi Azikiwe University, Nnewi Campus, Anambra State, Nigeria.

Copyright (c) 2021 Author(s) retain the copyright of this article. This article is published under the terms of the Creative Commons Attribution Liscense 4.0. 
Although the world has recorded a dismal landmark of 1.6 Million Covid-19 related deaths, it is however evident that herd immunity is still far-fetched [5]. Vaccination therefore will be paramount to achieve a level of population immunity that will help to further prevent the Covid-19 spread [5]. Covid-19 vaccine development began as soon as SARs COV-2 was identified as the causative agent to coronavirus [6][7][8]. On March, 2019, the first Covid-19 vaccine, an mRNAbased vaccine was developed by Moderna Inc in USA, later a non-replicating vector-based vaccine was developed by China's CanSino Biologics. Subsequently, other vaccines including DNA-based, inactivated, live-attenuated, sub-unit and replicating viral vector-based have also been developed [6][7][8].

Vaccines found to be highly effective will enable uptake than those with low effectiveness. It is also possible that people may perceive a pandemic vaccine as less safe based on its newness and perceived lack of testing [7][8]. With the arrival of the Covid-19 vaccine to Nigeria on 2nd of March, 2021, the high priority groups which include the health care providers will be among the first receivers of the vaccine [9]. Therefore, health care providers' intention to accept the vaccination themselves as well as recommending it to their patient depends on their knowledge and attitude to the vaccine. Reports have shown that healthcare providers with bad attitude, aversion and poor knowledge towards vaccination will likely transfer such hostile attitudes to patients and tend to recommend vaccines less frequently [10].

Since a prolonged sustenance of confidence in vaccination depends on the interaction between patients and healthcare providers [11][12] and research has also shown that the quality, content and dissemination of health education about vaccines will help in promoting the acceptability, reduce hesitancy and guide informed decisions about vaccination [13]. Therefore, there is need to explore the enablers and perceived risks to Covid-19 vaccine acceptance among health workers who are the front-liners in the war against the pandemic which this study aimed to achieve.

\section{Material and methods}

\subsection{Study Location}

Nigeria is a country in West Africa with a population of approximately 202 million people.

There are three major ethnic groups in Nigeria; Hausa, Igbo and Yoruba. Nigeria is made up of 36 states and the Federal Capital Territory. These states are located within six geopolitical zones in Nigeria: North-Central, North-East, NorthWest, South-East, South-South and South-West. In as much as, Nigeria is rich in natural resources with crude oil as its main export, the majority still live in poverty with a minimum monthly wage of N30,000 (approximately $\$ 80$ a month).According to the World Bank, Nigeria is classified as a low-income country with a rise in unemployment as the core reason for elevated poverty levels, regional and gender inequalities, and socio-political problems [14].

\subsection{Study Design}

A snowball sampling technique was utilized in the distribution of the online questionnaires sent in the form of a link through social media outlets such as WhatsApp, Face book and emails.

\subsection{Study Participants}

Health care providers in Nigeria aged 18 years and above with access to the internet and social media.

Inclusion criteria: Health care providers in Nigeria and aged 18 years and above who were willing to participate in the study.

Exclusion criteria: Respondents who declined informed consent, health care workers who are not in Nigeria, even though they may be Nigerian nationals and respondents less than 18years.

\subsection{Data Collection/Tools}

An online survey was created using the free software Google form and distributed through social media networks (WhatsApp, Facebook, emails). Data were collected within 4 weeks interval. The questionnaire had four sections; informed consent, participant's demographics, information on enablers of Covid-19 vaccine acceptability and perceived risks of covid-19 vaccine. The participants' demographics assessed include age, gender, state of residence and geographical zones, ethnicity, religion, marital status and health care sector. 


\subsection{Statistical Analysis}

Analysis was performed using Statistical Software Package SPSS version 22.0. Descriptive statistics (including mean and standard deviations) were calculated for the numerical variables.

\subsection{Consent and Ethical Approval}

The guidelines on research involving the use of human subjects according to Helsinki declaration was adhered to. Online consent was obtained from participants. Participants were allowed to leave the survey at any time they desired. Confidentiality of information was assured, and the survey was anonymous.

\section{Results}

Table 1 Socio-demographic features of respondents

\begin{tabular}{|c|c|c|}
\hline Characteristics & Frequency $n=445$ & Percentage (\%) \\
\hline \multicolumn{3}{|l|}{ Age (years) } \\
\hline$\leq 20$ & 4 & 0.9 \\
\hline $21-30$ & 162 & 36.4 \\
\hline $31-40$ & 221 & 49.7 \\
\hline $41-50$ & 49 & 11.0 \\
\hline $51-60$ & 8 & 1.8 \\
\hline$>61$ & 1 & 0.2 \\
\hline \multicolumn{3}{|l|}{ Gender } \\
\hline Male & 292 & 65.6 \\
\hline Female & 153 & 34.4 \\
\hline \multicolumn{3}{|l|}{ Marital status } \\
\hline Single & 206 & 46.3 \\
\hline Married & 233 & 52.4 \\
\hline Divorce/Separated & 2 & 0.4 \\
\hline Cohabiting & 3 & 0.7 \\
\hline Widowed & 1 & 0.2 \\
\hline \multicolumn{3}{|l|}{ Religion } \\
\hline Christianity & 400 & 89.9 \\
\hline Muslim & 35 & 7.9 \\
\hline Traditionalist & 2 & 0.4 \\
\hline Others & 8 & 1.8 \\
\hline \multicolumn{3}{|l|}{ Profession } \\
\hline Doctor & 170 & 38.2 \\
\hline Nurse & 37 & 8.3 \\
\hline \multicolumn{3}{|l|}{ Radiographer/Imaging } \\
\hline Scientist & 11 & 2.5 \\
\hline Public Health Workers & 41 & 9.2 \\
\hline Dentist/Dental Therapist & 1 & 0.2 \\
\hline Optometrist & 4 & 0.9 \\
\hline Scientific Officer & 6 & 1.3 \\
\hline Medical Laboratory Scientist & 121 & 27.2 \\
\hline Pharmacist & 36 & 8.1 \\
\hline Medical Record Officer & 5 & 1.1 \\
\hline
\end{tabular}




\begin{tabular}{|l|l|l|}
\hline Physiotherapist & 8 & 1.8 \\
\hline Hospital Cleaner & \multicolumn{2}{|l|}{} \\
\hline Cadre Hospital & \multicolumn{2}{|l|}{10.1} \\
\hline Primary Healthcare Centre & 30 & 6.7 \\
\hline General Hospital & 49 & 11.0 \\
\hline Specialist Hospital & 41 & 9.2 \\
\hline Teaching Hospital & 134 & 30.1 \\
\hline Private Practice & 84 & 18.9 \\
\hline Public Health Organizations & 9 & 2.0 \\
\hline NGO & 88 & 19.8 \\
\hline Ministry of Health & 10 & 2.2 \\
\hline Geopolitical Zone & \multicolumn{2}{|l|}{} \\
\hline North Central & 60 & 13.5 \\
\hline North East & 43 & 9.7 \\
\hline North West & 29 & 6.5 \\
\hline South East & 157 & 35.3 \\
\hline South South & 105 & 23.6 \\
\hline South West & 51 & 11.5 \\
\hline
\end{tabular}

A higher proportion of the respondents were males, aged 31-40 years, Christian and medical doctors by profession.

Table 2 Enablers of Covid-19 vaccine acceptability

\begin{tabular}{|c|c|c|}
\hline Variables $* *$ & Frequency $n=445$ & Percentage (\%) \\
\hline Little or no side effects & 263 & 59.1 \\
\hline Approval by a Religious Leader & 34 & 7.6 \\
\hline Good knowledge & 267 & 60.0 \\
\hline Proven vaccine efficacy & 299 & 67.2 \\
\hline Full partner's support & 36 & 8.1 \\
\hline Vaccine safety & 330 & 74.2 \\
\hline Family support & 39 & 8.8 \\
\hline Exposure to potential Covid-19 patients & 135 & 30.3 \\
\hline Social/Cultural support & 29 & 6.5 \\
\hline Government support & 84 & 18.9 \\
\hline Institutional support & 96 & 21.6 \\
\hline If Vaccine is free & 151 & 33.9 \\
\hline
\end{tabular}

Out of the 445 respondents, factors identified that will enhance vaccine acceptance are vaccine safety $330(74.2 \%)$, followed by proven vaccine efficacy $299(67.2 \%)$ and the least identified factor was social/cultural support 29(6.5\%) 
Table 3 Perceived risks of Covid-19 vaccine

\begin{tabular}{|c|c|c|}
\hline Variables** & Frequency $n=445$ & Percentage (\%) \\
\hline \multicolumn{3}{|l|}{ Severity of virus will } \\
\hline greatly decline & 106 & 23.8 \\
\hline Clinical trial inadequate & 207 & 46.5 \\
\hline Clinical sequelae may result & 243 & 54.6 \\
\hline New virus strain may emerge & 187 & 42.0 \\
\hline Vaccine worsen co morbidity & 180 & 40.4 \\
\hline Vaccine affects immune system & 61 & 13.7 \\
\hline
\end{tabular}

The most common perceived risk identified in this study was clinical sequelae may result 243(54.6\%), followed by Clinical trial inadequate 207 (46.5\%) and vaccine affects the immune system was the least identified perceived risk $61(13.3 \%)$

\section{Discussion}

The study was conducted to assess the enablers and perceived risks of Covid-19 vaccination among healthcare providers in Nigeria. It was observed that safety of the vaccine, proven efficacy and good knowledge of the vaccine were enablers to the Covid-19 vaccine uptake. These finding shows that a higher proportion of health care providers were in support of the covid-19 vaccine under the presumption that the vaccine was proven effective. A study conducted in Indonesia corroborated with this finding which also noted that vaccine $95 \%$ effectiveness and good knowledge of the vaccine were identified as the enablers of the vaccine uptake [8].

Perceptions of risk are an inherent part of the decision-making process. In the current study, 243(54.6\%) perceived that a clinical sequalae may result later after they take the Covid-19 vaccine, 207(46.5\%) perceived that the clinical trial of the Covid-19 vaccine was inadequate and 187(42.0\%) perceived that a new virus strain may emerge and therefore, bring about another vaccine. In addition, 180(40.4\%) respondents perceived that the Covid-19 vaccine might worsen their co-morbidities and 61(13.7\%) showed concerns as they think the Covid-19 vaccine may affect their immune systems and make them more susceptible to new viral strains. When a pandemic arise and immediately when a new vaccine is released, there is so much excitement about a vaccine which is usually at its peak and this may cause people to want to get the vaccine but as delay sets in people starts to nurture some perceive thoughts in addition to social media and misinformation spread therefore contributing to what we experienced in this study where a palpable percentage of our respondents are already perceiving risks that will make them not to take the vaccine when it is made available.

\section{Limitations}

The selection bias could be related to be related to the sampling technique used. Also, the identified enablers and perceived risks were observed using a hypothetical vaccine, these may differ in real life situations.

\section{Conclusion}

Proven vaccine safety, proven efficacy and good knowledge were identified as enablers of the covid-19 vaccine while clinical sequalae and inadequate trials were noted as the perceived risks of covid-19 vaccine uptake among health care providers. Therefore, the need for training of health care providers on the safety of the covid-19 vaccine cannot be over emphasized as they bridge the gap of information for their patients.

\section{Compliance with ethical standards}

\section{Acknowledgments}

We acknowledge all the health workers who in their busy schedule found it worthy to be part of this survey. 


\section{Disclosure of conflict of interest}

Authors declare that there is no competing interest.

\section{References}

[1] Johns Hopkins University \& Medicine. Coronavirus resource center: CoVID-19 dashboard by the center for systems science and engineering (CSSE). Johns Hopkins University (JHU); 2020. https://coronavirus.jhu.edu/map.html (accessed: 29th June 2020).

[2] World Health Organization. Coronavirus Disease 2019 (COVID-19) Situation Report https://www.who.int/docs/default-source/coronaviruse/situationreports/20200226-sitrep-37-covid19.pdf?sfvrsn=2146841e 2 .

[3] NCDC. Coronavirus COVID-19 Update [Internet]. 2021 [cited 2021 Mar 6]. Available from: https://covid19.ncdc.gov.ng/

[4] Ekwebene OC, Ogbuagu CN, Yanmeer ST et.al. Perception, knowledge and response to COVID-19 pandemic among traders in three major markets in Anambra State, Nigeria. Int J Health Sci Res. 2020; 10(12):213-221.

[5] https://www.who.int/news-room/spotlight/ten-threats-to-global-health-in-2019

[6] Lurie N, Saville M, Hatchett R, Halton J. Developing Covid-19 Vaccines at Pandemic Speed. N Engl J Med. 2020;382(21):1969-73.

[7] Sun X, Wagner AL, Ji J, Huang Z, Zikmund-Fisher BJ, Boulton ML, et al. A conjoint analysis of stated vaccine preferences in Shanghai, China. Vaccine. 2020;38(6):1520-5.

[8] Harapan H, Wagner AL, Yufika A, Winardi W, Anwar S, Gan AK, et al. Acceptance of a COVID-19 Vaccine in Southeast Asia: A Cross-Sectional Study in Indonesia. Front Public Heal. 2020;8(381):1-8.

[9] World Health Organization. COVID-19 vaccines shipped by COVAX arrive in Nigeria [Internet]. WHO Regional office for Africa. 2021 [cited 2021 Mar 6]. Available from: https://www.afro.who.int/news/covid-19-vaccinesshipped-covax-arrive-nigeria

[10] Naz H, Cevik F, Aykın N. Original Article Influenza Vaccination in Healthcare Workers. 2006.

[11] Schmitt HJ, Booy R, Aston R, et al. How to optimise the coverage rate of infant and adult immunisations in Europe. BMC Med. 2007;5 (1):1-8. doi:10.1186/1741-7015-5-11

[12] Asma S, Akan H, Uysal Y, et al. Factors effecting influenza vaccination uptake among health care workers: a multicenter cross-sectional study. BMC Infect Dis. 2016; 1-9. doi:10.1186/ s12879-016-1528-9

[13] The New Economy of Africa [Internet]. Available:https://www.cgdev.org/reader/new economy-africaopportunities-nigeriasemerging-technology-sector[Cited 2021 Jan 14].

[14] NigeriaOverview[Internet].Available:https://www.worldbank.org/en/country/nigeria/overview [Cited 2021 Jan 14]. 